Nama: Aninda Aprilia

Nim: 90100118031

\title{
KONSEP EKONOMI PADA MASA MERKANTILISME
}

Sejak dahulu sampai sekarang, praktek politik tidak bisa dilepaskan begitu saja dengan ekonomi. Kehidupan politik dan ekonomi selalii saling bertemu, saling mempengaruhi dan jalinmenjalin. Aktivitas-aktivitas politik karena itu amat sulit dipisahkan dari aktivitas-aktivitas ekonomi. Dalam setiap tindakan politik ada aspek ekonominya, demikian pula struktur perekonomian suatu masyarakat dapat mempengaruhi lembaga-lembaga politik, baik yang sudah ada maupun yang akan ada di kemudian hari. Joseph Crosey yang mengadakan penyelidikan khusus dan mendalam tentang hubungan ilmu politik dan ekonomi, seperti yang dikutip oleh Isjwara mengatakan; "Thatpoliticsandeconomic life have much to do with each other as remark matched inselfevidence only by theparallel observation thatpoliticscience andeconomics are of mutual interest.

Pandangan tentang ekonomi dikatakan oleh Adam Smith, bahwa "manusia berusaha memenuhi kebutuhannya, tetapi terbatas sumber”. Menurut Ibn Khaldun tentang politik-ekonomi, yaitu "negara adalah induk pasar, yang menjamin kegiatan ekonomi rakyatnya dan ekonomi sebagai penopang keutuhan negara".22 Ibn Khaldun juga menyatakan bahwa "ekonomi suatu negara akan bagus dan berkembang, selama ada keseimbangan antara kegiatan individu, persaingan dan peranan pemerintah". "Kerja yang tidak teratur akan membahayakan pertumbuhan ekonomi dan kezhaliman merupakan salah satu faktor yang menyebabkan kehancuran ekomomi”(Lilimantik 2015).

Ekonomi mempunyai peranan yang sangat penting dalam kehidupan, baik secara individual maupun kolektif. Setiap invidu, memerlukan ekonomi yang memadai untuk memenuhi keperluannya termasuk sandang, pangan dan papan atau tempat domisili. Secara kolektif , masyarakat juga memerlukan sarana umum seperti; jalan, sarana ibadah, sarana pendidikan, kesehatan, oleh raga dan sebagainya. Dalam rangka mewujudkan stabilitas, baik di tingkat Desa, Kecamatan, Kabupaten, Provinsi dan di ibu kota, peranan ekonomi sangatlah urgen. Tanpa kekuatan ekonomi, kehidupan dan segala aspeknya tidak akan dapat berjalan dengan baik. 
Pengembangan ekonomi, dapat diakukan dengan berbagai cara. Secara individual seseorang dapat mengembangkan ekonomi dengan cara buka usaha bengkel, bertani, mencari ikan di laut dan lainlain. Secara kolkan ektif orang mendirikan usaha bersama, seperti mendirikan Bank, perkebunan, koperasi, perumahan, dan sebagainya.(Mujiatun 2014)

Kesehatan menjadi suatu bagian dari sumber daya manusia selain pengetahuan, ketrampilan, serta sikap dan perilaku. Kesehatan menjadi dasar menentukan mampu tidaknya seseorang untuk beraktifitas yang baik. Sehingga, sangatlah wajar bila kesehatan masyarakat mendapatkan perhatian dan subsidi pembiayaaan dari pemerintah. Akan tetapi, sebagai bagian dari sumber daya dan kebutuhan yang primer, kesehatan menjadi daya tarik tersendiri untuk mendapatkan keuntungan. Selain besar kecilnya keuntungan, cara mendapatkan keuntungan tersebut juga dikritisi, karena berpotensi mengurangi kualitas pelayanan kepada peserta, merugikan keuangan pemerintah (BPJS Kesehatan), memungkinkan terjadinya subyektifisme pelayanan, sehingga merkantilisme pelayanan tidak dapat dihindarkan. Untuk itu, kontrol pada berbagai bagian dalam sistem kesehatan ini sangat diperlukan, utamnya agar tidak terjadi fraud yang bertujuan untuk mendapatkan klaim lebih banyak dari BPJS Kesehatan. Pengetahuan peserta tentang hak dan kewajibannya merupakan hal yang utama dalam pencegahan terjadinya merkantilisme, karena dari pesertalah tempat mulainya pelayanan tersebut.(Artana 2019)

Lilimantik, Emmy. 2015. “Kebijakan Ekonomi Internasional.”

Mujiatun, Siti. 2014. "Peran Pemerintah Tentang Pengembangan Perekonomian Dalam Perspektif Sistem Ekonomi Kapitalis, Sosialis, Dan Islam.” Analytica Islamica 3 (1): 97.

Artana, Wayan. 2019. "Merkantilisme Pelayanan Kesehatan." Dharmasmrti: Jurnal Ilmu Agama Dan Kebudayaan 19 (1): 85-92. https://doi.org/10.32795/ds.v10i1.339. 